\title{
BROADENING THE INFLUENCE OF ASSET MANAGERS THROUGH THE SIX PRINCIPLES OF PERSUASION
}

\author{
P.D. Swart ${ }^{1 *}$, P.J. Vlok ${ }^{1} \&$ J.L. Jooste ${ }^{1}$
}

\section{ARTICLE INFO}

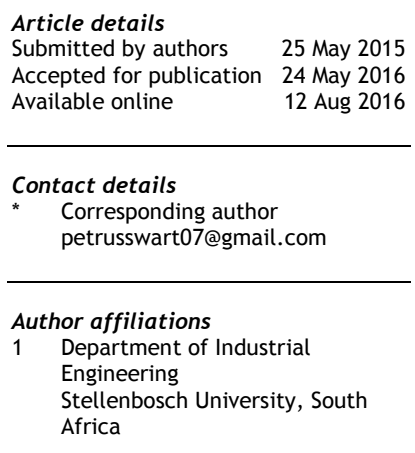

DOI

http://dx.doi.org/10.7166/27-2-1256

\section{ABSTRACT}

Asset managers (AMRs) have long struggled to influence others within their organisations to support Asset Management (AM) practices. This dilemma was further highlighted with the issuance of the $A M$ suite of standards, ISO 55000. This paper explores an alternative approach to existing influence and change management approaches. Social psychology, and more specifically Robert Cialdini's 'six principles of persuasion', have benefited advertisers, lawyers, and even waiters in their respective professions, by helping them to influence others and induce compliance. Fortunately, AMRs can now do the same. Implementing these principles offers numerous advantages and requires small, practical, and often costless changes that can make a large difference to their ability to influence and persuade others in an ethical way.

\section{OPSOMMING}

Batebestuurders (BBs) sukkel reeds lank om ander mense binne hulle organisasies te beïnvloed om batebestuurspraktyke te ondersteun. Hierdie dilemma is verder beklemtoon met die uitreiking van die versamelde Batebestuur (BB) standaarde, ISO 55000. Hierdie studie ondersoek ' $n$ alternatiewe benadering tot bestaande invloed- en veranderingsbestuursbenaderings. Sosiale sielkunde, en meer spesifiek Robert Cialdini se ses beginsels van oorreding, het al adverteerders, prokureurs en selfs kelners in hulle onderskeie beroepe bevoordeel. Dit het hulle gehelp om ander mense te beïnvloed en toegeeflikheid te verseker. Gelukkig kan BBs nou die selfde doen. Die implementering van hierdie beginsels bied verskeie voordele en vereis slegs klein, praktiese en meestal kostelose veranderinge wat kan lei tot groot verskille in hulle vermoë om ander mense op 'n etiese manier te beïnvloed en te oorreed.

ISO 55000, the international suite of standards for Asset Management (AM), was issued in early 2014. According to BSI [1], adoption of these standards enables organisations to achieve their objectives through effective and efficient management of their assets. There are various challenges that AMRs and businesses need to overcome with the implementation of a suite of standards such as ISO 55000 . One particular obstacle is employee resistance, which is exacerbated by the inability of AMRs to influence others within their organisation to support AM practices.

Until not long ago, maintenance was considered as nothing more than a necessary evil and regarded as inferior to production activities [2]. With little or no support from top management, the efforts of maintenance managers to influence horizontally (production managers) as well as downwards (subordinates) were often stifled or completely ineffective. Recently, however, there has been a paradigm shift from maintenance towards AM [3]. As a result of this shift, AMRs are experiencing the same dilemma that their maintenance counterparts experienced and, with their limited 
influence, are finding it difficult to enact the organisational changes needed to implement the ISO 55000 standards.

Organisational change needs to be managed at both a technical and a human level. Regrettably, the majority of businesses focus on the former and fail to recognise or understand the importance of the latter for implementing successful change [4]. Technical change is often easier to quantify, and therefore management can prepare change plans, strategies, and resources accordingly [5]. This is why the equally important human aspect of change is often overlooked [6].

People typically react in particular ways when faced with organisational change [7]. Scott and Jaffe [8] divide this process into four phases: initial denial, resistance, gradual exploration, and eventual commitment. Employee resistance, in particular, can undermine effective organisational change [9] and has been the cause of failure for various large-scale corporate change programmes [10]. According to Coghlan [11], employee resistance is the result of altering the status quo - that is, changing something that is familiar to employees to something that is less familiar to them. Despite being a challenge for initiators, O'Connor [12] believes that the focus of any change process should be the management of employee resistance.

Nilakant and Ramnarayan [13] state that "the psychology of persuasion is an important part of the tool-kit of a change manager". Social psychologists have put forward a vast number of persuasion taxonomies, strategies, and tactics. However, Cialdini [14] argues that the power of these persuasion techniques is governed by six fundamental psychological principles that direct human behaviour. Correctly applying these principles enables individuals to influence others, induce compliance, and ultimately lead people into agreement.

Guthrie [15] mentions that advertisers, marketers, and salespeople have all used Cialdini's 'six principles of persuasion' to motivate customers to purchase their products and services. Even waiters at restaurants have adopted some of these principles to increase their tip earnings [16]. There appears to be no discernible evidence in the literature that Cialdini's six principles of persuasion have been used in AM.

The skill to persuade is important to a leader [17]. According to the ISO 55000 standards, AM is based on a set of four fundamentals, of which leadership is one. It is stated that "leadership and commitment from all managerial levels is essential for successfully establishing, operating and improving asset management within the organisation" [1]. Thus to improve AM and successfully implement the ISO 55000 standards in an organisation, it is vital to gain the support of individuals within that organisation. In other words, the success of AM requires AMRs to focus on people and not only on systems, policies, and new technologies. According to Mitchell [18], "you have to know technology to do [something] but you will have to understand people to get it done". This assertion is supported by Woodhouse [19] who remarks that one can "ask any experienced Asset Manager where most of their improvements have come from and a very clear answer comes back - from the workforce!".

The purpose of this paper is to explore the use of Cialdini's six principles of persuasion within an AM environment. Each section introduces one principle supported by at least one case study to illustrate how the principle is applied. This is followed by an exploration of how AMRs can use these principles to gain support from others in their organisations. Benefits are anticipated for the broadening of an AMR's influence within their organisation. One expected benefit is helping AMRs to detach from the dilemma that has plagued maintenance managers: the inability to influence horizontally and vertically within an organisation. The second benefit is informing AMRs on how the six principles of persuasion can assist them in obtaining employee support for the adoption and implementation of the ISO 55000 standards. A third benefit is making AMRs aware of persuasion approaches that others might use on them to gain their support.

\section{THE PRINCIPLE OF RECIPROCITY}

The reciprocity principle is embedded in human society [20]. It pushes people to repay in kind, irrespective of the behaviour that was afforded to them [21]. Moreover, people who receive benefits such as gifts, favours, and concessions feel obligated to respond with positive behaviour of their own [22]. 
This sense of obligation is triggered by a feeling of indebtedness towards the benefactor. Henceforth, the beneficiary seeks to reimburse the benefactor in order to restore social equity, relieve internal discomfort, and avoid external shame. Also, society does not take kindly to people who accept without attempting to return positive behaviour [23].

A study conducted by Regan [24] demonstrates the power of the reciprocity principle. In this experiment, the participants were assigned randomly to either a control or an experimental group. Each participant was then paired with a confederate and asked to evaluate some artwork. Midway through the exhibition, the confederates left briefly and returned either empty-handed to the control group, or bearing a gift (e.g., a Coca-Cola soft-drink) for the experimental group. After the art evaluation, the confederates asked the participants whether they would be willing to purchase raffle tickets from them.

It was found that the experimental group was twice as willing to buy raffle tickets. Thus the unsolicited gift did in fact create an indebted feeling within the participants. Even though the prices for the raffle tickets were higher than the cost of the soft-drinks, the need to restore social equity triggered unequal exchanges between the confederates and the participants in the experimental group. This exchange inequality resulted in the confederates making a massive 500 per cent return on investment.

Gifts are an effective way of using reciprocity to gain support. However, favours and concessions can be equally productive. Cialdini [14] recommends using the 'reject-then-retreat' strategy. One starts by making a substantial concession which, as expected, gets turned down immediately. Next, a more modest concession is made that was the original intent. The other party feels indebted and therefore compelled to respond with behaviour that is complementary. Note however that this strategy needs to be executed skilfully. If the initial demand is seen as too extreme, the opposition will think one is negotiating in bad faith, which will impede further negotiations [25]. Prominent examples of people who employ this strategy include lawyers, policemen, and labour union officials.

What are the implications of reciprocity for asset managers? Give people what you wish to receive from them [26].

The principle confers a genuine 'first-mover advantage' for any AMR who is trying to cultivate positive attitudes and productive relationships in the workplace [27]. Therefore, a suggestion is for AMRs to initiate the first action, especially when building new or improving difficult relationships. AMRs could offer an incentive (favours, gifts, concessions, etc.) that should be genuine and personalised to ensure it is not construed as a bribe, but rather an act of good faith. An example of AMRs applying the principle of reciprocity is in improving collaboration between the maintenance and production departments. AMRs can ease tensions between these two parties by making maintenance staff available to production when they are short-staffed or facing unusual deadlines. Nevertheless, AMRs should only make this concession if it is appropriate to do so - that is to say, if there is little or no maintenance work requiring immediate attention. It follows from the reciprocity principle that the production department will be more accommodating should the maintenance department need their assistance in the future.

Regan's [24] study highlighted not only the exploitation potential of the principle, but also how the confederates controlled the situation. They decided, of all things possible, to give soft-drinks as gifts. The participants never asked for anything, and so had no say in the matter. The confederates also defined how the participants should repay them (raffle tickets). Similarly, maintenance managers can give incentives that are valuable to the other party, but also communicate what kind of repayment would assist them. It is important never to exploit the other party on purpose, as they will be more likely to reject future incentives.

Another example where the reciprocity principle supports an AMR is in creating a work environment that cultivates positive employee attitudes. By treating fellow workers with kindness, respect, and general optimism, AMRs can expect the same behaviour to be returned to them. Thus AMRs should first exhibit the behaviour they are seeking, before expecting it in return. 
People inherently want to act in a manner that is consistent with their commitments [28]. In other words, they want to remain true to their word. The likelihood of their honouring their word is improved when their commitments are voluntary [29], active [30], public [31], written, or verbal rather than unspoken [32].

The 'Drive carefully' study by Freedman and Fraser [33] illustrates the potential of the commitment principle. Home owners in a residential neighbourhood were randomly assigned to either a control or an experimental group. Both groups were then asked if they would allow a massive billboard to be erected on their front lawn. The board would completely obstruct the view of the house with a simple message that read "Be a safe driver". Seventeen per cent of the control group and 76 per cent of the experimental group agreed to this ludicrous request.

The results are explained by a single difference between the two groups. The experimental group was approached a week earlier about putting a small postcard in the front window of their house. It was identical to the billboard but modest in size, only three-by-three inches, and hence everyone agreed to this request. The study shows how small initial commitments can quickly escalate into more substantial ones [17]. Furthermore, internal pressure to align actions with self-image, along with external pressure to appear consistent to others, caused this reaction [34].

What are the implications of commitment and consistency for asset managers? People fulfil commitments that are voluntary, active, public, and written down [26].

Latham and Baldes [35] found that an individual's performance improves immediately after committing to a specific goal. The unfortunate reality, however, is that not all employee commitments are voluntary, active, public, or put into writing. This requires AMRs to be creative in how they obtain these commitments from employees.

AMRs should identify any values their employees value highly. It can be something such as building team spirit, working hard, or a devotion to others. Next, a connection should be established between these identified values and the commitments AMRs require from their employees. Finally, they should clearly communicate the relations between the values and the commitments to their employees. In doing this, employees are encouraged to take ownership of their commitments, as these are consistent with their own values.

To gain maximum benefit from this principle, Freedman and Fraser's [33] study revealed that the target person needs to make a minor initial commitment. AMRs need to ensure that this commitment is small enough for their employees to be able to fulfil it. It is only after the initial commitments have been met that more substantial requests should be made. Employees should be allowed sufficient time between the two commitments. The time should not be so long that they forget about the initial commitment, and not so short that they feel pressurised into the second commitment. Pressurising or threatening employees into commitment will be detrimental to the objective, and the commitments are likely to be experienced as burdens. Such a practice will impede long-lasting behavioural change and only cause resentment towards AMRs.

Asking employees to put their commitments into writing or to make them public is often problematic. Workers see this as doubting the truthfulness of their word and so consider it an insult or a personal attack. A subtler way would be to send them an email afterwards saying, for example, "Thank you, John, for being such a team player. I told Anna (Maintenance Manager) and Peter (Production Managers) about your commitment. We are all grateful for your help". The employees will realise their commitment is public, with the likelihood of improving their self-esteem with the knowledge that the AMR is discussing them among peers.

\section{THE PRINCIPLE OF SOCIAL PROOF}

In the face of uncertainty, people tend to look towards the actions and decisions of others to determine their own [36]. They follow the old adage of 'safety in numbers' or, according to Pennington and Schlenker [37], they conform to the position of the audience. 
Conformity also operates outside our conscious awareness. For example, behavioural mimicry is the phenomenon where one imitates the behaviour of another while interacting. Imitation includes the matching of postures, facial expressions, vocal characteristics, and mannerisms [38]. All of these are aimed at building rapport, creating liking, and promoting the development of social relationships [39].

A study conducted by Cialdini et al. [40] shows both the correct and the incorrect use of the social proof principle. Park officials at the Petrified Forest National Park, Arizona, were concerned by the alarming rate of theft of their petrified wood. To discourage visitors from stealing, signs displaying the following message were installed: "Your heritage is being vandalised every day by theft losses of petrified wood of 14 tons a year, mostly a small piece at a time". To the dismay of park officials, theft escalated after the installation of their signs. Though well intended, these signs were ineffective as they highlighted and inadvertently advertised the negative behaviour of previous visitors. New guests saw their conduct as commonplace, therefore acceptable, and consequently followed suit.

Using students as participants under controlled conditions at a university, Cialdini et al. [40] indicated a 2.92 per cent reduction in theft when a negatively-worded message was made positive. The former read, "Many past visitors have removed the petrified wood from the park, changing the state of the Petrified Forest", whereas the latter message read, "The vast majority of past visitors have left the petrified wood in the park, preserving the natural state of the Petrified Forest". When positive behaviour was highlighted, hence establishing social proof in the desired direction, the recipients of the message duly obliged with their actions.

What are the implications and benefits of social proof for asset managers? People follow the example of similar others [26].

The study underlines the effectiveness of peer persuasion. AMRs can apply this technique when making requests. By emphasising the actions of others, they appear impartial, objective, and therefore more credible.

For example, in seeking funding for a new AM initiative, AMRs arguments should include any other similar organisations that have implemented similar initiatives. Furthermore, AMRs should discuss the successes and challenges these organisations have experienced with the implementation of this initiative. They should also describe how this initiative will be unique to their own organisation, specifically whether it provides competitive advantage.

This is obvious, and it is often used as a strategy. An equally effective but less direct approach is to influence horizontally within the organisation. It is especially helpful when AMRs encounter or expect resistance from laggard employees. Before approaching the laggards directly, AMRs should identify a confidant or an influential person within the organisation to support the initiative. It should be someone these laggards trust and respect or whose opinion they value. The confidant should be asked to support the initiative and promote it during casual conversations. Only after the confidant's intercession should the AMRs approach these laggards directly. The AMRs will immediately be held in higher regard as they already have the support of someone the laggards hold in high regard.

\section{THE PRINCIPLE OF LIKING}

It is not surprising that, according to the principle of liking, people are increasingly willing to do favours and comply with requests brought forward by individuals they like [15]. Seethaler and Rose [29] list a number of factors that enhance liking, such as physical attractiveness, cooperation, compliments, similarity of background, attitudes, and even attire.

Studies have illustrated how these factors enhance liking and subsequently induce compliance. A good example for physical attractiveness is an experiment conducted by Reingen and Kernen [41]. They instructed attractive and less-attractive solicitors to approached individuals and say the following: "I'm collecting for the Heart Fund. Would you make a small donation?" The good-looking solicitors recorded nearly double the compliance rate of their counterparts; 42 per cent versus 23 per cent. 
Aune and Basil [42], on the other hand, demonstrate the role of similarity in liking. Students at a university campus were randomly approached by confederates and asked to donate money to a wellknown charitable organisation. Phrasing the request as, "Hi! I'm collecting donations for . Could you contribute something?" resulted in a 9.8 per cent compliance rate. However, when the confederates added that they were in fact also students at the university, compliance increased nearly fivefold. By establishing a similarity link, 47.1 per cent of the approached students complied and donated money.

What are the implications and benefits of liking for asset managers? People like individuals who are similar to them [26].

Whether someone finds an AMR physically attractive or not is beyond the AMRs' control. There are, however, other factors associated with the liking principle that are manageable. One such factor is similarity.

AMRs can use similarities to build relationships and forge friendships. Building a relationship creates the presumption of loyalty and trust. Compliments and praise have been found to be effective at creating liking. In fact, research has shown that the compliments do not even have to be true to have the desired effect [36]. However, it is advisable to remain genuine at all times to avoid the possibility of being seen as either disingenuous or unscrupulous.

Handing out compliments is especially difficult when relationships experience tension - or worse, are broken. The other person may be suspicious and misinterpret them as sarcastic. A subtler approach is therefore necessary. Even if adversaries do not get along with each other, they might respect or even admire one aspect of their opposition's life. AMRs should identify these aspects in their adversaries' lives. It can be workmanship, attention to detail, or devotion to family. As an alternative to compliments, AMRs can remark on the things they respect and admire about their adversaries. This should serve as the beginning of rebuilding their relationship.

Identifying similarities or aspects of someone else's life should not be tedious. A practical approach would be to spend the first few minutes of a meeting discussing anything other than work. This time should be used to discuss hobbies and backgrounds, for example. One should appear interested, establish similarities, and then start with the meeting. Also, informal discussions at work are sources of information when one is looking to learn more about the other person.

\section{THE PRINCIPLE OF AUTHORITY}

Akin to the principle of social proof, when faced with uncertainty, people tend to seek expert advice to aid their decision-making [21]. Their decisions and beliefs gravitate towards those of credible sources [43]. Both credibility and authority are enhanced when one is considered knowledgeable or an expert in that particular field. In fact, professional titles (professor, doctor, etc.) or even work uniforms (firemen, police officers, etc.) are sufficient in establishing the external appearance of authority [44].

It seems reasonable for hesitant people to defer important decision-making until they have sought professional counsel. For instance, when faced with legal issues, one should first speak to a lawyer. In the same way, a doctor should be consulted before taking any medicine. Contrary to these examples, authority can also induce startling human behaviour.

A famous and troubling illustration of the authority principle is a study conducted by Milgram [45]. In this experiment, an examiner told participants to administer electrical shocks to co-participants who gave the incorrect answers to a word-matching test. The co-participants were in on the experiment and were never actually shocked; instead, they theatrically pretended to experience shocks ranging from 15 to 450 volts. With each round of the test becoming increasingly difficult, the co-participants started making more mistakes and appeared to be in greater discomfort. The examiner kept telling the participants to continue shocking co-participants. Disturbingly, all forty of them kept inflicting shocks up until 300 volts. At this point, the co-participants had stopped moving and lay lifeless. In the following round, five participants refused to continue with the experiment, but astonishingly, twenty-six continued administering shocks until the maximum of 450 volts. Milgram found that the participants only continued administering electric shock because an authority figure (examiner) had told them to do so. 
What are the implications and benefits of authority for asset managers? People listen to individuals with expertise [26].

AMRs should avoid the mistake of thinking that their expertise is self-evident. Occupying an organisational leadership position does not guarantee respect, obedience, or compliance from fellow employees. Accolades on an office wall will inform people of achievements, but might serve to intimidate and alienate them as well. A more refined approach would be preferable.

Real estate agents often instruct their secretaries to politely mention their credentials before putting through a call [46]. AMRs can instruct their receptionists to do the same with phone calls and personal exchanges with other employees. The goal is to convey the credentials in an informative rather than boastful way. It can be something simple as "I will put you through to John. He has over 30 years' experience with pump failures", or "Problem with spare parts? Well, John is your man. He successfully implemented a major spare parts planning programme here six months ago". It goes without saying that these credential excerpts must be truthful.

AMRs themselves should not shy away from delineating their competence. Rather than announcing it or being forceful about it, they can bring it up in casual conversation a few minutes prior to a meeting. It should be presented in such a way that it forms part of the conversation. During meetings, one should also not discount other people's opinions or ideas. Even if they are incorrect or misguided, one should take the time to explain kindly the faults in their reasoning. AMRs can refer to prior experiences or complex disciplines that they have mastered to validate their contentions. All the while they are subtly showcasing their own competency.

\section{THE PRINCIPLE OF SCARCITY}

People learn from childhood that limited items and opportunities are generally harder and better to get than those that are plentiful [47]. The greater the extent of their rarity or unavailability, the more desirable [48] and valuable [49] they become. Likewise, exclusive information holds increased persuasive power and is, therefore, perceived to be of greater value [36].

Scarcity induces compliance because people feel their freedom of choice is being threatened [50]. The feeling is that if they do not act now, they will lose the opportunity to do so [15]. This is why it is more persuasive to frame offers in terms of what someone stands to lose instead of what they stand to gain [51]. A study conducted by Knishinsky [52] shows how the scarcity principle affected the purchasing decisions of wholesale beef buyers. First, these wholesalers were told that there would be an imminent beef scarcity because of unfavourable weather conditions abroad. They responded by doubling their orders. Following this, the wholesalers were told that the information was exclusive and that they were the first to find out. They reacted to this scoop by increasing their original order by a mammoth 600 per cent.

What are the implications and benefits of scarcity for asset managers? People value and desire what is scarce [26].

AMRs are tasked with managing limited resources such as time, money, and personnel on a daily basis. They know the dilemmas associated with balancing these resources in a way that creates value and minimises downtime. However, this knowledge should not just be seen as a burden, but rather as an opportunity to mobilise action.

For example, in the case where AMRs seek support for a new AM initiative, the scarcity principle can offer assistance in gaining support from others. When this initiative is presented to other people, AMRs should discuss all the scarcities involved, such as a closing window of opportunity. They should also make information about the initiative exclusive to those from whom they most need the support. Exclusivity should be highlighted by saying something like, "I thought I would show you first. I'll show everyone else next week". To conclude the argument, AMRs should phrase what the organisation stands to lose, rather than gain, through the implementation of this initiative.

Note however, that everything that is said has to be true. Support will be lost if one is duplicitous. If one says it is a closing window of opportunity or exclusive information, it has to be the case. 
The principles in the foregoing sections are discussed separately to ensure a clear understanding. However, the principles often overlap and work together in unison [36]. A case in point: Reingen and Kernen's [41] physical attractiveness study (principle of liking) cannot exclude the possibility of social proof influencing its results. Individuals who witnessed surrounding people (similar others) donating money would have felt inclined to act in a corresponding manner regardless of the physical attractiveness of the solicitors.

Also, just because AMRs can use all six of these principles does not mean that they should. It is up to the AMR to decide which principles they feel most comfortable applying and incorporating into their work-life. It should also be noted that perfecting these principles will require both time and effort. As with any new skill, dedication and hard work are paramount to success. Each AMR will be required to develop his or her own unique style in applying the principles. What works for some AMRs will not necessarily work for others.

The aim of this paper is to create awareness of persuasion approaches that could benefit AMRs. The six principles of persuasion that can assist AMRs in influencing horizontally and vertically within their organisations are discussed. In addition, these principles can help gain the employee the necessary support for the successful adoption and implementation of the ISO 55000 suite of standards. This paper also serves to raise awareness of how others apply the same approaches to persuade AMRs to support their agendas. As Cialdini [31] puts it, "by understanding persuasion techniques, we can begin to recognise strategies and thus truly analyse requests and offerings".

\section{REFERENCES}

[1] BSI. 2014. BS ISO 55000, 55001 and 55002 Asset Management Standards. BSI Standards. ISBN 9780580856242.

[2] Oke, S. 2005. An analytical model for the optimisation of maintenance profitability. International Journal of Productivity and Performance Management, 54, pp. 113-136.

[3] Amadi-Echendu, J.E. 2004. Managing physical assets is a paradigm shift from maintenance. In: International Engineering Management Conference.

[4] Arendt, C., Landis, R. and Mesieter, T. 1995. The human side of change - Part 4. IEE Solutions, pp. 2226.

[5] Tessler, D. 1989. The human side of change. Training and Development Journal, 43(3), pp. 26-32.

[6] Levine, G. 1997. Forging successful resistance. Bobbin, 39(1), pp. 146-166.

[7] Kyle, N. 1993. Staying with the flow of change. Journal of Quality and Participation, 14, pp. 34-42.

[8] Scott, C. and Jaffe, D. 1988. Survive and thrive in times of change. Development Journal, 42, pp. 25-27.

[9] Cummings, T.G. and Worley, C.G. 2009. Organization development \& change. 9th edition, Ohio: Southwestern College.

[10] Maurer, R. 1997. Transforming resistance. HR Focus, 74, pp. 9-10.

[11] Coghlan, D. 1993. A person-centred approach to dealing with resistance to change. Leadership and Organization Development Journal, 4, pp. 10-14.

[12] O'Connor, C.A. 1993. Resistance: The repercussions of change. Leadership \& Organization Development Journal, 14, pp. 30-36.

[13] Nilakant, V. and Ramnarayan, S. 2006. Change management: Altering mindsets in a global context. Response Bks. SAGE Publications.

[14] Cialdini, R. 2009. Influence. HarperCollins.

[15] Guthrie, C. 2004. Principles of influence in negotiation. Marquette Law Review, 87, pp. 829-835.

[16] Lynn, M. 2001. Restaurant tipping and service quality: A tenuous relationship. Cornell Hotel and Restaurant Administration Quarterly, 42(1), pp. 14-20.

[17] Hoy, W.K. and Smith, P.A. 2007. Influence: A key to successful leadership. International Journal of Educational Management, 21, pp. 158-167.

[18] Mitchell, J. 2012. Physical asset management course. Presented at University of Stellenbosch, Cape Town, June 2012.

[19] Woodhouse, J. 1997. What is asset management? Maintenance and Asset Management, 12, pp. 26-28.

[20] Gouldner, A.W. 1960. The norm of reciprocity: A preliminary statement. American Sociological Review, 25, pp. 161-178.

[21] Cialdini, R.B. 2001. Influence: Science and Practice. Allyn and Bacon.

[22] Groves, R.M., Cialdini, R.B. and Couper, M.P. 1992. Understanding the decision to participate in a survey. The Public Opinion Quarterly, 56, pp. 475-495.

[23] Gergen, K.J., Ellsworth, P., Maslach, C. and Seipel, M. 1975. Obligation, donor resources, and reactions to aid in three cultures. Journal of Personality and Social Psychology, 31(3), pp. 390-400.

[24] Regan, D.T. 1971. Effects of a favor and liking on compliance. Journal of Experimental Social Psychology, 7, pp. 627-639. 
[25] Schwarzwald, J., Raz, M. and Zvibel, M. 1971. The efficacy of the door-in-the-face technique when established behavioral customs exist. Journal of Applied Social Psychology, 9, pp. 576-586.

[26] Kaptein, M., Markopoulos, P., de Ruyter, B. and Aarts, E. 2009. Can you be persuaded? Individual differences in susceptibility to persuasion. In: Human-Computer Interaction-INTERACT 2009, Springer, pp. 115-118.

[27] Cialdini, R.B. 2001. Harnessing the science of persuasion. Harvard Business Review, Reprint R0109D, pp. 70-79.

[28] Cheng, R. and Vassileva, J. 2005. User motivation and persuasion strategy for peer-to-peer communities. In: Proceedings of the 38th Hawaii International Conference on System Sciences.

[29] Seethaler, R.K. and Rose, G. 2006. Six principles of persuasion to promote community-based travel behavior change. Journal of the Transportation Research Board, pp. 42-51.

[30] Baca-Motes, K., Brown, A., Gneezy, A., Keenan, E.A. and Nelson, L.D. 2012. Commitment and behavior change: Evidence from the field. Journal of Consumer Research, 39, pp. 1070-1084.

[31] Cialdini, R.B. 2007. The science of persuasion. Scientific American Mind, 14, pp. 70-77.

[32] Cioffi, D. and Garner, R. 1996. On doing the decision: The effects of active versus choice on commitment and self-perception. Personality and Social Psychology Bulletin, 22, pp. 131-147.

[33] Freedman, J.L. and Fraser, S.C. 1966. Compliance without pressure: The foot-in-the-door technique. Journal of Personality and Social Psychology, 4, pp. 195-202.

[34] Schlenker, B., Dlugolecki, D. and Doherty, K. 1994. The impact of self-presentations on self-appraisals and behavior: The power of public commitment. Personality and Social Psychology Bulletin, 20, pp. 20-33.

[35] Latham, G. and Baldes, J. 1975. The practical significance of Locke's theory of goal-setting. Journal of Applied Psychology, 60, pp. 122-124.

[36] Cialdini, R.B. and Goldstein, N.J. 2002. The science and practice of persuasion. Cornell Hotel and Restaurant Administration Quarterly, 43, pp. 40-50.

[37] Pennington, J. and Schlenker, B. 1999. Accountability for consequential decisions: Justifying ethical judgments to audiences. Personal Soc. Psychol. Bull., 25, pp. 1067-1081.

[38] Chartrand, T. and Bargh, J. 1999. The chameleon effect: The perception-behavior link and social interaction. J. Personal Soc. Psychol., 76, pp. 893-910.

[39] Bourgeois, P. and Hess, U. 2008. The impact of social context on mimicry. Biological Psychology, 77, pp. 343-352.

[40] Cialdini, R., Demaine, L., Sagarin, B., Barrett, D., Kelton, L. and Winter, P. 2006. Managing social norms for persuasive impact. Social Influence, 1, pp. 3-15.

[41] Reingen, P.H. and Kernen, J. 1993. Social perception and interpersonal influence: Some consequences of the physical attractiveness stereotype in a personal selling setting. Journal of Consumer Psychology, 2(1), pp. 23-38.

[42] Aune, K.R. and Basil, M.D. 1994. A relational obligations approach to the foot-in-the-mouth effect. Journal of Applied Social Psychology, 24(6), pp. 546-556.

[43] Eagly, A.H. and Chaiken, S. 1975. An attribution analysis of the effect of communicator characteristics on opinion change: The case of communicator attractiveness. Journal of Personality and Social Psychology, 32, pp. 136-144.

[44] Bushman, B. 1984. Perceived symbols of authority and their influence on compliance. Journal of Applied Social Psychology, 14, pp. 501-508.

[45] Milgram, S. 1963. Behavioral study of obedience. Journal of Abnormal and Social Psychology, 67, pp. 371378.

[46] Porter, J. 2014. A quick look into the six principles of influence. Retrieved from http://www.jrmyprtr.com/cialdini-six-principles-of-influence/. Accessed on 15 May 2015.

[47] Lynn, M. 1989. Scarcity effects on desirability: Mediated by assumed expensiveness? Journal of Economic Psychology, 10, pp. 257-274.

[48] Lynn, M. 1991. Scarcity effects on value: A quantitative review of the commodity theory literature. Psychology and Marketing, 8, pp. 53-57.

[49] Mazis, M.B. 1975. Antipollution measures and psychological reactance theory: A field experiment. Journal of Personality and Social Psychology, 31, pp. 654-660.

[50] Aggarwal, P., Jun, S.Y. and Huh, J.H. 2011. Scarcity messages. Journal of Advertising, 40(3), pp. 19-30.

[51] DeDreu, C.K.W. and McCusker, C. 1997. Gain-loss frames and cooperation in two-person social dilemmas: A transformational analysis. Journal of Personality and Social Psychology, 72(5), pp. 1093-1116.

[52] Knishinsky, A. 1982. The effects of scarcity of material and exclusivity of information on industrial buyer perceived risk in provoking a purchase decision. Arizona State University. 